\title{
Gambaran Postpartum Depression pada Figur Ayah
}

\author{
NATASYA VERGYANO REEVEN \& IKA YUNIAR CAHYANTI* \\ Fakultas Psikologi Universitas Airlangga
}

\begin{abstract}
ABSTRAK
Hampir $80 \%$ gangguan psikologis terjadi pada perempuan pasca melahirkan. Gangguan psikologis ini juga bisa dialami oleh suami pasca istrinya bersalin atau setelah lahirnya bayi. Salah satu masalah yang mungkin terjadi setelah kelahiran bayi untuk ayah adalah paternal post-natal depression atau postpartum depression. Maka dari itu penelitian ini bertujuan untuk menggali lebih jauh mengenai halhal yang dapat mengembangkan postpartum depression figur ayah dan apa saja yang dirasakan oleh figur ayah saat mengalami postpartum depression. Penelitian ini menggunakan pendekatan kualitatif dengan tipe penelitian Descriptive Phenomenological Analysis (DPA). Hasil penelitian menunjukkan bahwa hal yang dapat mengembangkan postpartum depression pada figur ayah antara lain; kurang tidur dan istirahat, merasa terputus dengan pasangan, adanya masalah perekonomian dan, adanya masalah perkerjaan. Figur ayah yang sedang mengalami postpartum depression juga merasakan hal-hal seperti; mudah marah, bekerja lebih banyak, kelelahan, konsentrasi yang buruk, perubahan nafsu makan, gejala fisik (kepala terasa berat, pusing dan, pegal-pegal), kemarahan dan ledakan.
\end{abstract}

Kata kunci: figur ayah, paternal post-natal depression, postpartum depression

\section{ABSTRACT}

Nearly $80 \%$ of psychological disorders occur in women after childbirth. This psychological disorder can also be experienced by husbands after their wives give birth or after the birth of a baby. One of the problems that may occur after the birth of a baby for a father is paternal post-natal depression or postpartum depression. Therefore, this study aims to explore more about the things that can develop postpartum depression in the father figure and what the father figure feels when experiencing it. This study uses a qualitative approach with the type of DPA research. The results of the study show that things that can develop postpartum depression in father figures include; lack of sleep and rest, feeling disconnected from a partner, economic problems and work problems. Father figures who are experiencing postpartum depression also feel things like; irritability, overwork, fatigue, poor concentration, changes in appetite, physical symptoms, anger and outbursts.

Keywords: father figure, paternal post-natal depression, postpartum depression

Buletin Penelitian Psikologi dan Kesehatan Mental (BRPKM), 2021, Vol. 1(1), 938-946

*Alamat korespondensi: Fakultas Psikologi Universitas Airlangga, Kampus B Universitas Airlangga Jalan Airlangga 4-6 Surabaya 60286. Surel: ika.yuniar@psikologi.unair.ac.id

Naskah ini merupakan naskah dengan akses terbuka dibawah ketentuan the Creative Common Attribution License (CC-BY-4.0) (http://creativecommons.org/licenses/by/4.0), sehingga penggunaan, distribusi, reproduksi dalam media apapun atas artikel ini tidak dibatasi, selama sumber aslinya disitir dengan baik. 


\section{PENDAHULUAN}

Mendapati buah hati tercinta akhirnya muncul dan lahir ke dunia merupakan suatu kebahagiaan tersendiri untuk pasangan. Bukan hanya wanita, pria pun merasakan kebahagiaan yang sama besarnya. Saat menjadi ayah baru, pria akan merasakan perasaan bahagia, bangga, gembira, dan terberkati (Shinta, 2018).

Peran ayah (fathering) adalah peran yang dimainkan seorang ayah dalam kaitannya dengan tugas untuk mengarahkan anak menjadi mandiri dan berkembang secara positif, baik secara fisik dan psikologis (Hart, 2002). Menurut Parmanti \& Purnamasari (2015) peran ayah dalam keluarga selain sebagai seorang pemimpin dalam keluarga, ayah juga berperan sebagai penyedia kebutuhan anak, memberikan afeksi, merawat anak, dan mendukung anak untuk mencapai keberhasilan. Peran ayah dalam mengasuh anak disela-sela kesibukannya sangat membutuhkan pembagian waktu yang efektif, selain membagi waktunya untuk bekerja ayah harus membagi waktu untuk mengasuh anak-anaknya (Wahyuningrum, 2011).

Menurut Cooklin, dkk (2015) tantangan saat menjadi ayah baru adalah ketika adanya tekanan untuk mempertahankan atau meningkatkan tingkat pendapatan dan mempertahankan kinerja pekerjaan ditengah tuntutan baru yaitu mengasuh bayi, kurang tidur atau istirahat, dan adanya perubahan pada hubungan pasangan. Cooklin, dkk (2015) menyebutkan bahwa dalam menyeimbangkan peran sebagai ayah dan pekerja, ayah yang bekerja dengan jam kerja yang panjang, kerja shift, atau situasi pekerjaan yang tidak fleksibel melaporkan adanya konflik pekerjaan-keluarga yang lebih tinggi dan ayah lebih merasa tertekan. Adanya tekanan untuk menjadi pencari nafkah yang sukses membuat beberapa ayah tidak bisa memiliki waktu bersama anak mereka seperti; menemani mereka ke acara orang tua-anak, dan pertemuan medis (Chin, dkk., 2011). Menurut Shinta (2018) salah satu masalah yang mungkin terjadi setelah kelahiran bayi untuk ayah adalah paternal post-natal depression atau postpartum depression. Ayah yang baru pertama kali memiliki bayi, memiliki resiko sebesar $10 \%$ untuk mengalami Postpartum Depression (Kim \& Swain, 2007).

The Diagnostic and Statistical Manual of Mental Disorders, Fifth Edition (DSM-5) mendefinisikan depresi "dengan onset peripartum" sebagai episode depresi mayor selama kehamilan atau dalam empat minggu setelah melahirkan (APA, 2013). Meskipun kriteria ini dapat digunakan untuk mendiagnosis postpartum depression pada wanita dan pria, mungkin ada perbedaan kecil dalam onset dan presentasi antara pria dan wanita (Scarff, 2019). Depression pihak ayah mungkin terlihat selama kehamilan, biasanya segera mereda setelah melahirkan dan muncul kembali dalam periode 3 sampai 6 bulan pascapartum (Paulson \& Bazemore, 2010), dan semakin parah selama tahun pertama pascapartum (Matthey, dkk., 2000). Selain itu, mudah tersinggung, bimbang, dan mudah emosi mungkin lebih sering terlihat pada pria yang mengalami postpartum depression (Berg \& Ahmed, 2016; Madsen \& Juhl, 2007).

Biasanya, depresi yang tidak diobati akan memburuk, dan hal ini dapat memengaruhi pernikahan, karier, dan keluarga (Hibbert, 2021). Menurut Field (2018) postpartum depression menyebabkan rasa menderita pada diri sendiri, terganggunya fungsi hidup, dan menurunnya kualitas hidup. Postpartum Depression juga menyebabkan kesulitan membentuk kedekatan hubungan ayah dengan anak, anak mengalami psikopatologi, gangguan emosi, sulit berteman dan berinteraksi dengan orang lain, gangguan perkembangan komunikasi, persepsi, kemampuan motorik dan cenderung berperilaku anarkis (Thurgood, dkk., 2009). 
Melihat fenomena ini peneliti tertarik untuk mengetahui bagaimana gambaran postpartum depression yang dialami oleh figur ayah, agar hasil dari penelitian ini dapat menjadi salah satu informasi bagi orang di sekitar figur ayah dan ayah sendiri pun untuk tau bahwa ayah juga dapat mengalami postpartum depression agar dapat mencegah atau mengatasi postpartum depression pada figur ayah.

\section{METODE}

\section{Desain Penelitian}

Dalam penelitian ini, peneliti menggunakan pendekatan penelitian kualitatif. Tipe penelitian kualitatif yang digunakan dalam penelitian ini adalah menggunakan pendekatan fenomenologi desktriptif, peneliti ingin mendeskripsikan atau menggambarkan bagaimana setiap pertisispan memberi arti untuk pengalamannya, hasil dari deskripsi ini adalah paham apa inti/esensi dari pengalaman seluruh partisipan (La Kahija, 2017). Tipe penelitian fenomenologi desktriptif dilakukan dalam penelitian ini sesuai dengan fokus penelitian untuk menjawab bagaimana gambaran postpartum depression yang dialami oleh figur ayah.

\section{Partisipan}

Partisipan penelitian adalah sumber utama untuk sebuah penelitian yang memiliki data mengenai variabel yang diteliti dan yang akan dikenai kesimpulan pada akhir penelitian (Azwar, 2011). Terkait dengan permasalahan yang menjadi topik penelitian, maka partisipan yang akan digunakan sebagai sumber data bagi peneliti, memiliki kriteria seperti; laki-laki, sudah menikah, partisipan mengalami menjadi ayah, partisipan mengalami postpartum depression. Untuk mendapatkan partisipan dengan kriteria ini peneliti menggunakan alat ukur postpartum depression. Alat ukur yang digunakan dalam penilaian kondisi psikologis ayah adalah Edinburgh Postnatal Depression Scale (EPDS). EPDS dipilih sebagai instrument penelitian karna EPDS merupakan instrument baku dan berdasarkan hasil penelitian sebelumnya dinyatakan bahwa instrument tersebut telah teruji dan diakui validitas dan reliabilitasnya. Menurut Tsai (2013, dalam Misrawati dkk., 2018) EPDS memiliki nilai sensitivitas 0.94 dan spesifisitas 0.77. Menurut Abadian Sharif (dalam Misrawati dkk., 2018) juga mengatakan bahwa kuesioner EPDS memiliki keakuratan sebesar 90\%.

\section{Strategi Pengumpulan Data}

Teknik pengambilan data dalam penelitian ini adalah wawancara. Jenis wawancara dalam penelitian ini adalah wawancara dengan menggunakan pedoman umum. Peneliti menggunakan pedoman wawancara bersifat umum yang mencantumkan isu-isu yang berkaitan dengan topik penelitian tanpa menentukan urutan pertanyaan. Pedoman wawancara digunakan untuk menjaga pembicaraan yang terjadi ketika wawancara, sehingga tetap berada dalam fokus penelitian. Sementara itu, tema yang telah disusun dalam pedoman wawancara dapat berkembang dalam setiap pelaksanaan wawancara sesuai dengan jawaban yang diberikan partisipan.

\section{Analisis Data}

Teknik analisis data yang digunakan peneliti adalah Descriptive Phenomenological Analysis (DPA). Adapun langkah-langkah analisis pada penelitian DPA menurut La Kahija (2017) yaitu: (1) Peneliti mengembangkan sikap fenomenologis dengan menjalankan epoche; (2) Peneliti menyadari munculnya 
ciri atau karakteristik dari fenomena yang diteliti baik itu ciri atau karakteristik yang nyata atau fiktif; (3) Peneliti menjalankan variasi imajinatif, dengan bantuan variasi imajinatif; (4) Peneliti melihat semua ciri atau karakteristik yang muncul dan mengintuisi atau inti dari fenomena (pengalaman) yang diteliti; (5) Peneliti berhati-hati mendeskripsikan esensi atau inti dari apa yang sudah ditemukan.

\section{HASIL PENELITIAN}

\section{Hal yang Berperan dalam Mengembangkan Postpartum Depression}

\section{Partisipan 1}

Sejak lahirnya bayi, partisipan mengalami beberapa perubahan dalam hidupnya. Pertama partisipan mengalami perubahan pola tidur dari yang sebelumnya mempunyai waktu tidur sebanyak 7 sampai 8 jam, setelah memiliki bayi partisipan hanya mempunyai waktu tidur sebanyak 3 jam saja. Yang berarti waktu istirahat partisipan juga semakin berkurang dari biasanya. Hal ini dikarenakan partisipan sering terbangun di malam hari.

Intensitas kedekatan partisipan dengan sang istri juga mengalami perubahan. Dimana sejak lahirnya bayi, partisipan jarang mempunyai waktu berduaan saja dengan sang istri. Hal ini disebabkan karena selalu ada bayi diantara partisipan dan sang istri.

Bayi partisipan lahir bertepatan dengan adanya pandemi COVID-19. Rumah sakit tempat partisipan bekerja pun memberlakukan pemotongan gaji sebanyak 50\% dari gaji utama dan hal ini menyebabkan partisipan mengalami masalah dalam hal perekonomian.

Selain mengalami masalah dalam hal perekonomian, partisipan juga mengalami masalah atau kendala dalam hal pekerjaannya. Hal ini dikarenakan rumah sakit tempat partisipan bekerja juga menambah jam kerja. Dari yang sebelumnya hanya bekerja selama 8 jam, saat pandemi COVID-19 ini menjadi bekerja selama 10 jam.

\section{Partisipan 2}

Sejak lahirnya bayi, partisipan mengalami beberapa perubahan dalam hidupnya. Pertama partisipan mengalami perubahan pola tidur, karena saat malam hari partisipan akan terbangun setiap 3 jam sekali. Yang berarti waktu istirahat partisipan juga semakin berkurang dari biasanya.

Partisipan merasa tantangan utama yang dihadapinya adalah perubahan emosi yang dikarenakan keadaan istri partisipan yang melahirkan secara sesar. Dimana istri partisipan diharuskan istirahat total dan tidak bisa melakukan hal apapun selain terbaring di atas tempat tidur. Sehingga partisipan harus mengambil alih pekerjaan-pekerjaan yang biasanya dikerjakan oleh istri partisipan. Selain itu partisipan juga kerap kali terpancing emosinya saat sang istri emosi.

Setelah lahirnya bayi, istri partisipan diharuskan istirahat total dan otomatis partisipan sebagai suami yang akan mengambil alih pekerjaan-pekerjaan itu, dan hal ini menyebabkan partisipan mengalami kendala atau masalah dalam hal perkerjaannya. 


\section{Hal-Hal yang Dirasakan Figur Ayah saat Mengalami Postpartum Depression}

\section{Partisipan 1}

Setelah lahirnya bayi, partisipan merasa lebih mudah marah atau kesal karena hal-hal kecil, yang sebelumnya tidak pernah dipermasalahkan oleh partisipan itu sendiri. Contohnya partisipan merasa kesal dan marah saat istri partisipan menyajikan makanan, tetapi partisipan merasa tidak sesuai dengan keinginannya. Padahal, partisipan sebelumnya bukan termasuk orang yang pemilih dalam hal makanan.

Setelah lahirnya bayi partisipan merasa dirinya harus bekerja dengan keras dalam bekerja untuk memenuhi tuntutan dan tanggung jawab yang semakin bertambah, dari yang sebelumnya hanya seorang suami sekarang menjadi suami dan orang tua.

Partisipan seringkali merasa sulit berkonsentrasi atau sulit fokus saat bekerja karena partisipan memikirkan keadaan perekonomiannya. Contohnya saat partisipan bekerja tiba-tiba terfikirkan apakah uang belanja yang telah diberikan kepada istrinya cukup untuk memenuhi kebutuhan rumah tangganya atau tidak.

Partisipan juga merasakan adanya perubahan pada nafsu makannya. Dimana partisipan merasa nafsu makannya berkurang dan merasa lebih ingin minum.

Ada saat-saat di mana partisipan ingin meledakkan amarah, yaitu saat uang belanja yang telah partisipan berikan kepada sang istri ternyata tidak dapat mencukupi kebutuhan rumah tangganya dan mengharuskan partisipan memakai uang tabungan.

\section{Partisipan 2}

Setelah lahirnya bayi, partisipan merasa lebih mudah marah atau kesal dan, merasa mudah lelah. Partisipan merasa marah dan kesal di saat tubuh partisipan lelah tetapi partisipan tidak bisa beristirahat dikarenakan harus mengambil alih urusan rumah tangga yang sebelumnya dikerjakan oleh sang istri. Partisipan merasa lebih mudah lelah juga karena partisipan harus melakukan pekerjaan rumah tangga tersebut. Bahkan saat membayangkan semua pekerjaan yang harus partisipan lakukan, partisipan bisa langsung merasa lelah.

Partisipan merasa ingin cepat menyelesaikan pekerjaan kantornya karena partisipan tau bahwa ada pekerjaan lain yang menanti partisipan di rumah. Partisipan juga merasa sulit untuk berkonsentrasi atau fokus terhadap pekerjaan kantornya karena memikirkan pekerjaan-pekerjaan lain yang harus ia kerjakan di rumah dan akhirnya pekerjaan kantor partisipan menjadi terkendala dan tertunda.

Partisipan juga merasakan perubahan nafsu makan. Dimana nafsu makan partisipan menurun. Selain itu, partisipan juga terkadang mengalami penyakit fisik seperti kepala terasa berat, pusing, dan pegalpegal.

Ada saat-saat dimana partisipan ingin meledakkan amarah, yaitu saat target pekerjaan kantor belum tercapai tetapi disaat yang bersamaan ada pekerjaan rumah tangga yang harus diselesaikan. 


\section{DISKUSI}

Penelitian ini melibatkan dua partisipan yang mendapatkan skor 12 dan 11 pada skala EPDS. Dari hasil penggalian data melalui wawancara, ditemukan bahwa kedua partisipan mengalami beberapa hal yang dapat mengembangkan postpartum depression seperti; kurang tidur atau istirahat. Setelah lahirnya bayi, waktu tidur kedua partisipan mengalami penurunan yang signifikan. Hal ini dikarenakan pada saat malam hari kedua partisipan harus terjaga, di mana seharusnya pada saat malam hari adalah waktu untuk tidur dan mengistirahatkan tubuh. Hal ini sejalan dengan perkataan Hibbert (2021) bahwa kurangnya tidur dapat mengembangkan gejala kecemasan dan depresi.

Setelah lahirnya bayi, waktu kebersamaan partisipan 1 dengan sang istri semakin berkurang, hal ini terjadi karena bayi partisipan selalu ada di antara mereka. Bisa dikatakan bahwa partisipan 1 merasa terputus dengan pasangannya. Hal ini sesuai dengan pernyataan dari Hibbert (2021) bahwa setelah lahirnya bayi, seringkali seorang istri gagal menyadari bahwa suaminya juga menginginkan waktu kebersamaanya.

Seperti yang dijelaskan oleh Hibbert (2021) salah satu hal lain yang berkontribusi terhadap postpartum depression adalah adanya masalah dengan keuangan atau pekerjaan. Hal ini ditemukan pada partisipan 1, karena partisipan mengalami permasalahan perekonomian, di mana tempat partisipan bekerja memberlakukan pengurangan gaji sebanyak 50\% dari gaji utama di saat pandemi COVID-19 ini. Hal ini juga otomatis membuat partisipan 1 mengalami kendala dalam pekerjaan karena partisipan 1 merasa kesuliatan untuk berkonsentrasi atau fokus saat bekerja karena memikirkan keadaan perekonomiannya. Sedangkan partisipan 2 mengalami permasalahan dalam hal pekerjaan. Hal ini dikarenakan selain bekerja di kantor, partisipan 2 juga harus melakukan pekerjaan rumah tangga karena karena sang istri tidak bisa melakukan hal tersebut setelah lahirnya bayi.

Dari hasil penggalian data melalui wawancara juga ditemukan bahwa partisipan mengalami gejalagejala ini. Pertama mudah marah, hasil dari penggalian data ditemukan bahwa hal ini dialami oleh kedua partisipan. Jika partisipan 1 merasa mudah marah karena hal-hal kecil, contohnya partisipan 1 merasa marah dan kesal ketika sang istri menyajikan makan yang tidak sesuai dengan keinginanannya. Padahal, partisipan 1 sebelumnya bukan termasuk orang yang pemilih saat makan. Sedangkan, partisipan 2 akan merasa kesal dan marah ketika tubuhnya lelah dan ingin beristirahat tetapi, ada pekerjaan rumah tangganya belum terselesaikan dan partisipan 2 seringkali terpancing emosinya saat sang istri emosi.

Selanjutnya, mempunyai keinginan untuk bekerja lebih banyak. Di mana partisipan 1 ingin bekerja lebih banyak karena merasakan adanya tuntuntan untuk dapat memenuhi kebutuhan rumah tangganya di tengah keadaan pekerjaannya yang terkena imbas dari pandemi COVID-19. Sedangkan, partisipan 2 ingin lebih banyak bekerja saat di kantor karena ingin lebih cepat menyelesaikan pekerjaan kantornya yaitu memenuhi target dari atasannya, sehingga partisipan bisa pulang lebih cepat untuk melakukan pekerjaan rumah tangga. Lalu, partisipan 2 juga meraskan kelelahan karena selain bekerja di kantor partisipan juga harus melakukan pekerjaan rumah tangga. Bahkan, saat membayangkan semua pekerjaan yang harus partisipan 2 lakukan, partisipan 2 bisa langsung merasa lelah dan karena hal ini juga yang menyebabkan partisipan 2 mengalami gejala fisik seperti; kepala terasa berat, pusing dan, pegal-pegal.

Ditemukan juga bahwa terjadi adanya perubahan nafsu makan. Hal ini dialami oleh kedua partisipan. Partisipan 1 merasa nafsu makannya berkurang dari biasanya dan lebih ingin minum. Sedangkan partisipan 2 hanya merasa nafsu makannya yang berkurang dari biasanya. 
Selanjutnya kedua partisipan mengalami konsentrasi yang buruk. Partisipan 1 mengalami sulit berkonsentrasi saat bekerja karena memikirkan keadaan perekonomiannya. Sedangkan, partisipan 2 mengalami sulit berkonsentrasi saat bekerja karena memikirkan pekerjaan-pekerjaan lain yang harus dilakukan saat di rumah dan akhirnya pekerjaan kantor partisipan menjadi tertunda dan terkendala.

Terakhir, kedua partisipan juga mengalami kemarahan dan munculnya keinginan untuk meledakkan amarah. Partisipan 1 merasakan adanya dorongan untuk meledakkan amarah ketika uang belanja yang telah partisipan 1 berikan kepada sang istri ternyata tidak dapat mencukupi kebutuhan rumah tangganya dan mengharuskan partisipan 1 memakai uang tabungan. Sedangkan, partisipan 2 merasakan adanya dorongan untuk meledakkan amarah ketika target pekerjaan kantor belum tercapai tetapi disaat yang bersamaan ada pekerjaan rumah tangga yang harus diselesaikan juga.

Seperti yang telah dipaparkan, dari hasil temuan ini kedua partisipan mengalami beberapa gejala depresi yang sesuai dengan DSM-5 seperti; adanya penurunan nafsu makan, merasakan adanya rasa kelelahan, adanya penururnan konsentrasi dan hal ini menyebabkan penderitaan yang bermakna dalam fungsi pekerjaan atau keluarga. Kedua partisipan juga mengalami gejala lain seperti; mudah tersinggung dan mudah emosi. Hal sesuai dengan pernyataan Berg \& Ahmed (2016) dan Madsen \& Juhl (2007) gejala lain yang mungkin muncul pada ayah saat mengalami postpartum depression adalah mudah tersinggung, merasa bimbang dan, mudah emosi. Gejala lain yang muncul pada partisipan adalah merasa ingin lebih banyak bekerja, adanya gejala fisik (sakit kepala, nyeri otot, masalah perut / pencernaan), kemarahan dan ledakan.

Saat kedua partisipan merasa emosi atau jika ada masalah, mereka cenderung lebih memilih untuk memendam emosinya dan menyelesaikan masalahnya sendiri juga. Walau kedua partisipan terkadang merasa lelah dan tertekan, kedua partisipan merasa memang hal ini adalah bentuk tanggung jawabnya sebagai suami dan orang tua. Kedua partisipan lebih berusaha untuk mempersabar diri atas keadaannya saat ini.

\section{SIMPULAN}

Berdasarkan hasil penelitian dan diskusi yang telah dipaparkan di atas, ada beberapa kesimpulan dari penelitian ini. Pertama, ada beberapa hal yang dapat mengembangkan postpartum depression pada figur ayah seperti; kurang tidur atau istirahat, terjadi perubahan hubungan antara partisipan dengan pasangannya, adanya masalah perekomomian dan adanya masalah dalam hal pekerjaan. Kedua, saat figur ayah mengalami postpartum depression ada beberpa hal dirasakan oleh figur ayah seperti; merasa mudah emosional (marah), merasa ingin bekerja lebih banyak, sering merasa kelelahan, mengalami konsentrasi yang menurun atau buruk, mengalami perubahan nafsu makan (nafsu makan yang menurun), mengalami gejala-gejala fisik (kepala terasa berat, pusing dan, pegal-pegal), merasakan kemarahan yang tak tertahankan dan ingin meledakan amarah. Ketiga, Saat figur ayah merasakan emosi (marah) atau jika ada masalah, mereka cenderung lebih memilih untuk memendam emosinya dan menyelesaikan masalahnya sendiri juga. Walau kedua partisipan terkadang merasa lelah dan tertekan, kedua partisipan merasa memang hal ini adalah bentuk tanggung jawabnya sebagai suami dan orang tua. Kedua partisipan lebih berusaha untuk mempersabar diri atas keadaannya saat ini. 


\section{UCAPAN TERIMAKASIH}

Terima kasih kepada seluruh partisipan yang telah bersedia atas berkontribusinya terhadap penelitian ini, terima kasih pula kepada Fakultas Psikologi Universitas Airlangga yang telah memfasilitasi penelitian ini, semoga manfaat penelitian ini bisa dirasakan secara luas khususnya pada bidang Psikologi.

\section{DEKLARASI POTENSI TERJADINYA KONFLIK KEPENTINGAN}

Natasya Vergyano Reeven dan Ika Yuniar Cahyanti tidak bekerja, menjadi konsultan, memiliki saham, atau menerima dana dari perusahaan atau organisasi manapun yang mungkin akan mengambil untung dari diterbitkannya naskah ini.

\section{PUSTAKA ACUAN}

American Psychiatric Association. (2013). In: Diagnostic and Statistical Manual of Mental Disorders (5th ed.). American Psychiatric Association.

Azwar, S. (2011). Reliabilitas dan Validitas. Pustaka Pelajar.

Berg, A. R., \& Ahmed, A. H. (2016). Paternal perinatal depression. The Nurse Practitioner, 41(10), 1-5. https://doi.org/10.1097/01.NPR.0000499558.20110.82

Chin, R., Daiches, A., \& Hall, P. (2011). A qualitative exploration of first-time fathers' experiences of becoming a father. Community Practitioner: The Journal of the Community Practitioners' \& Health Visitors' Association, 84(7), 19-23. http://www.ncbi.nlm.nih.gov/pubmed/21941706

Cooklin, A. R., Giallo, R., Strazdins, L., Martin, A., Leach, L. S., \& Nicholson, J. M. (2015). What matters for working fathers? Job characteristics, work-family conflict and enrichment, and fathers' postpartum mental health in an Australian cohort. Social Science \& Medicine, 146, 214-222. https://doi.org/10.1016/j.socscimed.2015.09.028

Field, T. (2018). Paternal Prenatal, Perinatal and Pospartum Depression. A Narrative Review. J Anxiety Depress, 1, 102.

Hart, J. (2002). The Importance of Fathers in Children's Asset Development.

Hibbert, C. (2021). Postpartum Depression and Men: The Facts on Paternal Postnatal Depression / Dr. Christina Hibbert. http://www.drchristinahibbert.com/postpartum-depression-men-the-facts-onpaternal-postnatal-depression/

Kim, P., \& Swain, J. E. (2007). Sad dads: paternal postpartum depression. Psychiatry, 4(2), 35-47. http://www.ncbi.nlm.nih.gov/pubmed/20805898 
La Kahija, Y. F. (2017). Penelitian fenomenologis. Jalan memahami pengalaman hidup. Kanisius.

Madsen, S. A., \& Juhl, T. (2007). Paternal depression in the postnatal period assessed with traditional and male depression scales. The Journal of Men's Health \& Gender, 4(1), 26-31. https://doi.org/10.1016/j.jmhg.2006.10.017

Matthey, S., Barnett, B., Ungerer, J., \& Waters, B. (2000). Paternal and maternal depressed mood during the transition to parenthood. Journal of Affective Disorders, 60(2), 75-85. https://doi.org/10.1016/S0165-0327(99)00159-7

Misrawati, Dewi, Y. I., \& Amir, Y. (2018). EFEKTIFITAS MEDIA BOOKLET UNTUK MENINGKATKAN KONDISI PSIKOLOGIS SUAMI SETELAH ISTRI BERSALIN. Jurnal Ners Indonesia, 8(2), 179-190. https://doi.org/10.31258/jni.8.2.179-190

Parmanti, \& Purnamasari, S. E. (2015). PERAN AYAH DALAM PENGASUHAN ANAK. InSight, 17(2).

Paulson, J. F., \& Bazemore, S. D. (2010). Prenatal and postpartum depression in father and its association with maternal depression: a meta-analysis. Journal of the American Medical Association, 303, 19.

Scarff, J. R. (2019). Postpartum Depression in Men. Innovations in Clinical Neuroscience, 16(5-6), 11-14. http://www.ncbi.nlm.nih.gov/pubmed/31440396

Shinta, L. A. (2018). KEPUASAN MARITAL SEBAGAI HUBUNGAN DEPRESI PASCA DASAR PATERNAL. Jurnal Skolastik Keperawatan, 4(2), 25-31. https://doi.org/10.35974/jsk.v4i2.713

Thurgood, S., Daniel, B. S., \& Williamson, M. D. (2009). Postpartum depression (PPD). American Journal of Linical Edicine ${ }^{\circledR}, 6(2)$.

Wahyuningrum, E. (2011). Peran Ayah (Fathering) Pada Pengasuhan Anak Usia Dini (sebuah kajian teoritis). Psikowacana, 10. https://ris.uksw.edu/jurnal/read/kode/j00778 